\title{
INSTITUTIONAL PROBLEMS OF FINANCIAL CAPITAL MOBILIZATION IN MODERN RUSSIAN ECONOMY
}

\author{
Igor Barhatov $^{1}$, Ekaterina Biruykova², Igor Afanasev ${ }^{3}$
}

\begin{abstract}
This article views the mechanism and modern forms of financial capital mobilization in risky and uncertain conditions of the economic environment. From the perspective of the institutional approach, there is a group of problems typical for two different financial capital mobilization models: the bank loans market and the stock market. It reveals some contradictions of capital mobilization mechanism through bank lending by a critical assessment of subjective and purely subject-object relations; the major participant currently is the State. The features of the process of investing in a portfolio of securities in the current environment of high volatility of systematic and specific nature are defined, which ultimately determine the need to revise the prerequisites of classical portfolio theory and the development of new algorithms for redistribution of capital.

Solving the problem of the role of the State in the financial capital mobilization will allow the mechanism to adjust itself in the direction of growth in bank lending instruments. Simultaneously, there is an increase in the growth rate in the real sector of the Russian economy. The proposed mathematical apparatus of fuzzy set theory, based on uncertainty factors variety of the economic system being considered, is capable of minimizing the portfolio investment risk.
\end{abstract}

JEL Classification Numbers: A11, C40, G1, DOI: http://dx.doi.org/10.12955/cbup.v2.447

UDC Classification: 336.7

Keywords: capital, mobilization, financial risk, fuzzy set theory, institutional approach, portfolio theory, Russian economy

\section{Introduction}

Complexity of interaction of elements within the modern economic systems, the process of transformation of the Russian economy, and many internal and external factors determine the order of appearance of the phenomenon, "economy of uncertainty." Its main quality is the need for management, in this case, financial decisions based on inaccurate and incomplete information.

The end result of portfolio investment design may thus differ materially from those tasks and sometimes even contradict them, due to constant changes in the level of economic and political factors influence which is typical of the current state of instability in the world system of social and other character. This circumstance requires constant monitoring and adjustment of administrative decisions in the mobilization of financial capital — a review of existing modeling algorithms based on the choice of an adequate mechanism for predicting the resulting symptoms.

As the credit mechanism of capital mobilization poses a different kind of problem, "economy of uncertainty" leads to the transformation of the very principles of credit relations where redistribution is the basis when moving lendable value and its ability to generate additional income as a percentage (payment for a loan).

\section{Literature review}

Most modern theories of portfolio investment are based on the classical theory of Markowitz (Markowitz, 1952). Global financial crisis (The Great Recession of 2009), which manifested itself in a significant decrease in assets liquidity, increase in volatility, appearance of high correlation between asset classes, etc., has become a major test of Markowitz portfolio theory effectiveness.

\footnotetext{
${ }^{1}$ Igor Barhatov, Chelyabinsk State University, Russian Federation, ecoba@csu.ru

${ }^{2}$ Ekaterina Biruykova, Chelyabinsk State University, Russian Federation, birukova@csu.ru

${ }^{3}$ Igor Afanasev, Chelyabinsk State University, Russian Federation, afanasev@csu.ru
} 
All portfolio theories, which arose as a result of "accretion" of specific features of the current time on the classical H. Markowitz portfolio theory, can be divided into three types:

1. behavioral patterns;

2. quantitative models;

3. "reconsideration" model.

Theory of behavioral finance by Lin (2012) considers the irrationality of investment decisions. The model is effective in explaining investment decisions post factum, making it very difficult to use for a reliable forecast.

Researchers, committed to quantitative methods, focus on analysis of historical data of the financial markets in order to find events affecting the occurrence of various distribution functions of income return of investment portfolio, which determines the possible error due to the emergence of factors of a new order.

"Reconsideration" model is the third direction in the framework of modern portfolio theories. In the framework of the "reconsideration" models, the concept of "Black Swans" (Taleb, 2008) can be mentioned. Practically, this concept does not reveal new patterns for simulation or mathematical analysis of risk and return of an investment portfolio, since, by definition, unpredictable and random events have a much more significant impact on the financial market than expected.

Study of the problems of financial institutions and, in particular, the capital market began in the late $18^{\text {th }}$ century. An enormous contribution to the development of theoretical and methodological problems of loan capital has been made by foreign scientists-representatives of classical economic school: Smith, Marshall, Marx, Hilferding, Böhm-Bawerk, Galbraith, Clark, and Robinson.

One of the most prominent studies on problems of mobilizing of financial capital is the work of Hilferding, "Finance capital" (Hilferding, 1910), in which he revealed the contradictions of credit mechanism. Hilferding (1910) described credit relations in detail, in particular, revealing the essence of the various forms of loan. Hilferding widely described the possibility of such debt instruments as bills of exchange and checks, as well as shares and, especially, their circulation and use.

Problem of capital mobilization in the financial market has been widely described in the paper of Fischer, "Debt deflation theory of the Great Depression" (Fisher, 1933). In his work, Fisher described the mechanism of deflation associated with increased volume of loans. He was convinced that the only way out of debt deflation was to conduct reflation-measures to increase the money supply and to reduce taxes, leading to a return to the previous pre-deflated price level.

Among Russian researchers of the problems of capital mobilization, it is necessary to highlight the work of Barkhatov. In his work, "The stock market in the transformation of the Russian economy" (Barkhatov, 2009), he identified two groups of factors (both affecting positively and negatively), which determined the state of convergence and future development of financial market institutions. Among them are:

- the state of developed stock markets

- further development of the global currency markets

- the state of the global oil market and base metals markets

- the prospects for reform of the Russian electricity sector

- the state of the institution of property

\section{Data and methodology}

Modern securities market defines new conditions of the investment portfolio, which greatly complicates the mechanism for capital mobilization. Conditions for adequate high-risk system and 
specific financial projections must specify the type, especially, statistical data, which are subject to investment analysis.

- The distribution of securities return is not, in most cases, statistically normal because unexpected processes, so-called "heavy tails," exist.

- The original data models have significant variations in time.

- A variety of risks of investment portfolios, e.g. the risk of trust, leverage, etc., does not permit taking them all into account in the simulation.

- The resonance condition in the financial markets is more common in practice than allowed in theory.

In turn, the modern financial market participants also have a subjective, psychological component of the vector of managerial decision making (Palley, 2010) and are divided into three types:

1. "hedge" borrowers, who are free to pay off both the principal amount and the interest;

2. "speculative" borrowers, who are due to available funds and can only repay the value of accrued interest;

3. "Ponzi" borrowers, who expect only the steady rise in the cost of the asset and new loans.

The theory of fuzzy sets is based on the concepts introduced in the scientific revolution in the work of Zadeh (2005). Operating with fuzzy intervals with the necessary input data, ultimately, decisionmakers and other stakeholders get the final fuzzy interval for each performance targets of an established investment portfolio. Thus, this mechanism allows for a greater extent, compared with the classical portfolio theory, considering the phenomenon of the "economy of uncertainty."

Instability of the financial system and the uncertainty of conditions in financial transactions determine the development of new approaches and methods for the analysis of processes of capital mobilization. In conditions of the high business risks, new challenges in the study of trends in particular loan market are given as follows:

- determination of the degree of influence of the credit market monopolization on efficiency of the real economy;

- determination of the degree of participation in the processes of mobilization and concentration of various capital-borrowing actors, namely, the State;

- determination of the effectiveness of individual tools of capital borrowing in different models of capital raising;

- development of cycles of lending activity to assess the extent of its impact on economic growth.

Existing methods of technical analysis of the financial market are not always able to take into account all the factors affecting the market conditions and develop appropriate predictions of its dynamics. In the context of Russia's economic reality, the situation is complicated by the transformation of property relations between subjects of borrowing and the emergence of "personal unions." In this connection, it is necessary to use a complexity of better tools and methods to assess trends of capital mobilization under the aspects of "uncertainty" and "risk." An example of this method is the cluster analysis, the basics of which were described by the mathematician, Trion (Trion, 1939). Applied to the analysis of financial market, cluster analysis performs the following tasks:

- development of financial markets classification;

- research of useful conceptual schemes of market participants grouping;

- generation of hypotheses based on research data; 
- checking of hypotheses or research to determine whether the group of subjects, allocated by one way or another, are present in the data given.

In our opinion, the study of the processes of capital mobilization through the mechanism of the credit market must provide the following clusters: private lenders, the State, syndicates, and financialindustrial groups. After clustering, it is necessary to calculate and evaluate trends of the indicators characterizing the efficiency of subjects of borrowing, presented in Figure 1.

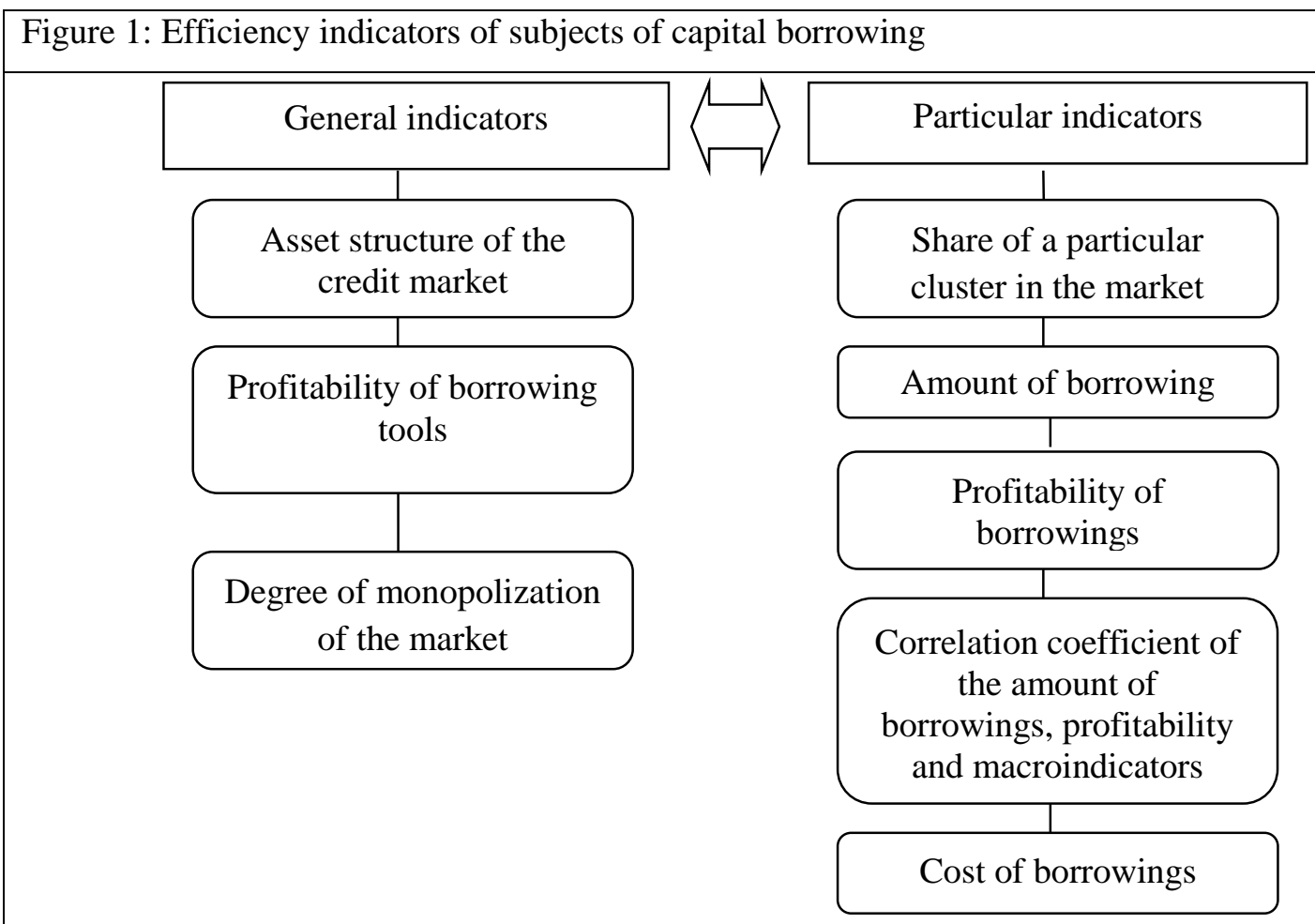

\section{Source: Authors}

It is necessary to evaluate the closest relationship between the activities of a particular group of subjects (cluster) and the country's economy as a whole, by the indicators given; to take the group as a basis; to build on it the credit cycle with its corresponding "financial bubbles" and "credit crunch"; and to take into account the influence of market factors. The resulting cycle is necessary to impose on the overall economic development cycle over a certain period, and to conduct a comparative analysis to identify the relationship between the credit activity of a specific cluster and the growth of the economy. Using further methodology for constructing the multiple regression models, it would be possible to evaluate the behavior of specific subjects of borrowings, due to the influence of endogenous and exogenous factors of the financial market, and its impact on the behavior of economic growth and industry efficiency.

\section{Results and Discussion}

Current stage of development of the Russian economy is characterized with a high degree of risk and uncertainty that affect the level of business risks and significantly slow the mobilization of financial capital. Thus, based on the expert assessments, the most relevant types of business risks in Russia are defined, and presented in Table 1. 
CBU INTERNATIONAL CONFERENCE ON INNOVATION, TECHNOLOGY TRANSFER AND EDUCATION

Table 1: Types of business risks in Russia (basic types and the average level of business risk)

\begin{tabular}{|c|c|c|}
\hline Type of risk & Definition & $\begin{array}{c}\text { The average level of } \\
\text { risk in Russia }\end{array}$ \\
\hline Percentage & $\begin{array}{l}\text { The risk of loss that may be incurred by employers in } \\
\text { connection with changes in market interest rates }\end{array}$ & $9-10$ \\
\hline Country & $\begin{array}{l}\text { The risk of loss in connection with the investment of } \\
\text { funds in companies under the jurisdiction of the } \\
\text { country with an unstable social and economic situation }\end{array}$ & $9-10$ \\
\hline Liquidity risk & $\begin{array}{l}\text { The risk associated with the possibility of losses due to } \\
\text { the implementation of the security changes quality } \\
\text { assessment }\end{array}$ & $8-10$ \\
\hline Capital & $\begin{array}{l}\text { The overall risk for all investments, the risk that the } \\
\text { investor will not be able to release the invested funds } \\
\text { without incurring losses }\end{array}$ & $7-10$ \\
\hline Inflationary & $\begin{array}{l}\text { The risk that with high inflation the income got from } \\
\text { invested funds can depreciate (in terms of real } \\
\text { purchasing power) faster than they grow }\end{array}$ & $7-10$ \\
\hline Temporal & $\begin{array}{l}\text { The risk of investing in the wrong time, which } \\
\text { inevitably entails losses }\end{array}$ & $6-8$ \\
\hline $\begin{array}{c}\text { The risk of } \\
\text { legislative changes }\end{array}$ & Unexpected loss of legislative regulation & $6-10$ \\
\hline Operating & $\begin{array}{l}\text { The risk of loss arising from the malfunction of } \\
\text { computer systems for processing information related to } \\
\text { investment funds }\end{array}$ & $5-10$ \\
\hline Selective & $\begin{array}{l}\text { The risk of a wrong choice for the business object in } \\
\text { comparison with other options }\end{array}$ & $5-6$ \\
\hline
\end{tabular}

Source: Authors

Development of portfolio theories in Russia has its own laws and features. Firstly, the economic entity carrying out the structure formation process of the investment portfolio in modern conditions has a probability of "excess return," which is due to overly risky state of the Russian stock market. Secondly, the diversification of the Russian security market is difficult to fulfill because of the limited liquidity of the investment portfolio tools, as well as the presence of a high degree of correlation between them. Thirdly, systematic risk factor generally dominates in the formation of the expected profitability of the investment portfolio in Russian's transforming economy.

The main types of portfolio investment risks are the following:

- Systematic risk is the risk of variability of the security market return in general. It is not associated with a particular security and is non-diversifiable.

- Specific risk is the risk associated with investing in specific securities. Specific risk is diversifiable and lowered. Existing types of specific risks characteristic of the Russian economy are presented in Figure 2.

Political, economic, legal, and other risks redistribute flows of financial capital mobilization, making it difficult to predict the key parameters of the investment portfolio. Starting from the $4^{\text {th }}$ quarter of 2012, a large share of Russian issuers is drawn to foreign markets, which undoubtedly is a negative factor for the development of Russia's economy in the current period. 


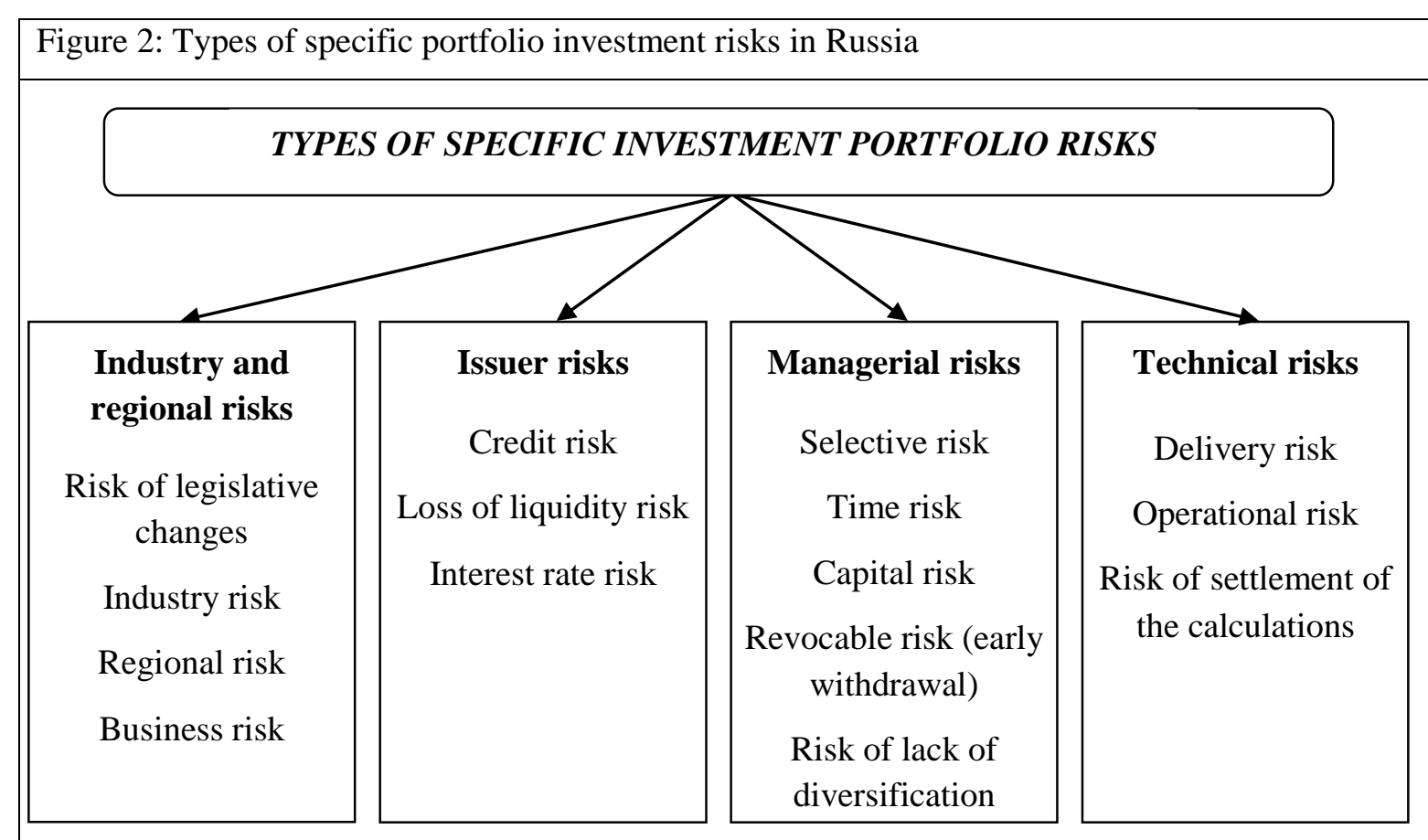

\section{Source: Authors}

In turn, the sectoral structure of the capitalization of the Russian stock market is practically unchanged for 5 to 8 years, which reduces the investment attractiveness of this segment of the financial market.

Unlike the stock market, the credit market in the contemporary economy is exposed to fewer risks, but the degree of their influence on the efficiency of commercial banks and other economic agents is high enough. An example of this is the constant emergence of so-called "financial bubbles" that are formed in the financial market due to the excess bubbling of prices for the underlying assets in inflation. Inflating financial bubbles is very beneficial for the economic situation, namely bank loans, as the collateral value of the underlying assets, for which large loans are being issued, is growing, and thereby attracts more banks to invest through lending mechanism. However, in modern conditions, economic actors wishing to obtain a short-term income for the rapid increase in prices, speculators, emerge quickly. They create the so-called "speculative demand," which leads to increased production of the underlying assets that are not really consumed and are purchased for the purposes of resale.

Thus, one of the most important functions of a bank loan is violated - the flow of capital in the industry most in need of it. Financial capital gets there where you need the most expensive production assets, but not in those areas of the real economy that are experiencing a real need to modernize and upgrade production funds, including the expense of attracted loans.

In our opinion, the phenomenon of financial bubbles is explained by behavioral function of financial market; the basis of which is the emergence of "financial illusions," which is a preferred tendency of entities to perceive nominal value of financial assets, not their true purchasing power. Financial illusions occur due to subjective psychological characteristics inherent to individual subjects, such as unjustified optimism and confidence in the future, and faith in a stable and prosperous situation of the financial market. In the context of globalization of the market, most of its members take some common misconceptions; and such characteristics become collective. Financial illusion becomes universal and provokes the formation of the illusory perception of the market situation, which leads to an overestimation of each individual participant, their entire collection of fair value of financial assets, and the emergence of speculative demand. 
CBU INTERNATIONAL CONFERENCE ON INNOVATION, TECHNOLOGY TRANSFER AND EDUCATION

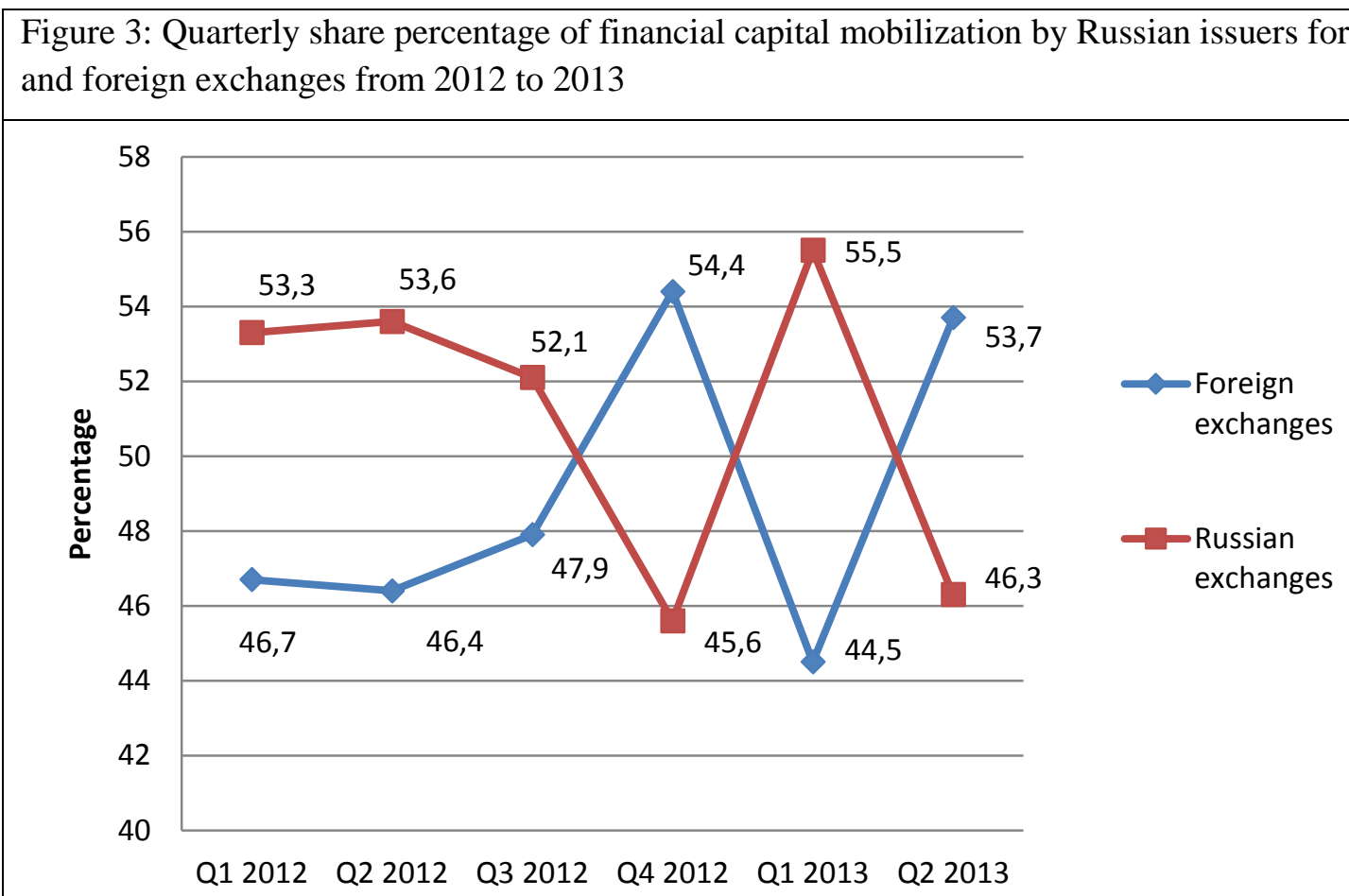

Source: Authors

Table 2: Quarterly percentage of capitalization by industry sectors in the Russian stock market from 2012 to 2013

\begin{tabular}{|c|r|r|r|r|r|r|}
\hline Sector & Q1 2012 & Q2 2012 & Q3 2012 & Q4 2012 & Q1 2013 & Q2 2013 \\
\hline Oil and Gas & 50.4 & 50.3 & 51.4 & 50.4 & 49.1 & 49.1 \\
\hline Financial & 13.1 & 13.4 & 13.4 & 13.4 & 15.3 & 16.1 \\
\hline Metallurgy & 10.5 & 10.8 & 9.5 & 9.6 & 8.6 & 7.6 \\
\hline Electricity & 8.8 & 7.3 & 7.6 & 6.8 & 6.1 & 5.1 \\
\hline Chemical & 4.2 & 4.9 & 4.8 & 5.6 & 4.8 & 4.9 \\
\hline Telecommunications & 3.8 & 3.8 & 3.9 & 4.6 & 6.7 & 6.7 \\
\hline Trading & 1.7 & 2.0 & 2.0 & 2.3 & 2.8 & 3.7 \\
\hline Transportation & 1.3 & 1.3 & 1.4 & 1.3 & 1.4 & 1.5 \\
\hline Engineering & 1.1 & 1.1 & 0.9 & 1.2 & 0.9 & 0.7 \\
\hline Mining & 1.1 & 1.1 & 1.0 & 1.2 & 1.3 & 1.4 \\
\hline Food processing & 1.0 & 1.2 & 1.2 & 0.9 & 0.2 & 0.2 \\
\hline Coal industry & 0.9 & 0.9 & 0.8 & 0.7 & 0.5 & 0.3 \\
\hline Other & 2.1 & 2.1 & 1.6 & 1.7 & 1.8 & 2.1 \\
\hline
\end{tabular}

Source: Authors

The emergence of financial illusions leads to an increase in lending. However, this is not due to growth in assets of the banking system, but rather because of the illusion of income in the future from the use of credit resources created, which are often not supported by actual wealth or other assets. 
Another feature of the modern processes of capital mobilization in the credit market is the transformation of the principles of credit. In the formation and development of credit relations, the mechanism to capital mobilization relied on objective-subjective form of interaction between the lender and the borrower. Its essence was to provide loan capital on the terms of payment, taking into account the real cost of credit resources and urgency, the actual duration of economic cycles of borrowers, control of target spending of credit resources, and differentiated approach to the borrower and its activities.

In modern conditions of developed capitalism, credit relations are carried out in a purely subjective form, or a form of so-called "personal unions." This is a form of splice in capitalist monopolies between themselves and the State. In the context of the study of capital mobilization through the credit facility, a personal union can be defined as the interpenetration of the management structures of commercial banks acting as lenders, businesses acting as borrowers, and the State acting as a controller of the movement of loan capital processes. One form of such interpenetration is the financial and industrial group. Despite the advantages of this form of integration, there are some significant drawbacks as follows:

1. a high risk of loan defaults caused by the overvalued confidence to the borrower, especially if it is the State itself, which is simultaneously the owner within the group;

2. a large dependence of the borrower from the lender even after repayment of the loan and interest;

3. the emergence of new forms of loans with deferred payments, prolongation of terms of return, the presence of favorable conditions for the issue, which is often disadvantageous to the lender and can be the cause of business profits;

4. monopolistically low interest rates on loans, which results in displacement of participants with low volume of assets from the market.

Figure 4 shows the general dynamics of capital borrowing by Russian corporations in the credit market 10 years of from 2002 to 2011. The figure shows that the amount of borrowing capital grew gradually and reached its peak value of loans to the private sector of 447.7 billion U.S. dollars, in 2010. But, this is not the highest indicator among developed countries. If we calculate the ratio of external debt of the private sector to GDP, Russia by such indicator is in the 6th place, behind the UK, France, Germany, the US, and Japan.

Figure 4: Dynamics of Russian corporations borrowing capital in the financial market from 2002 to 2011 (in billions of US dollars)

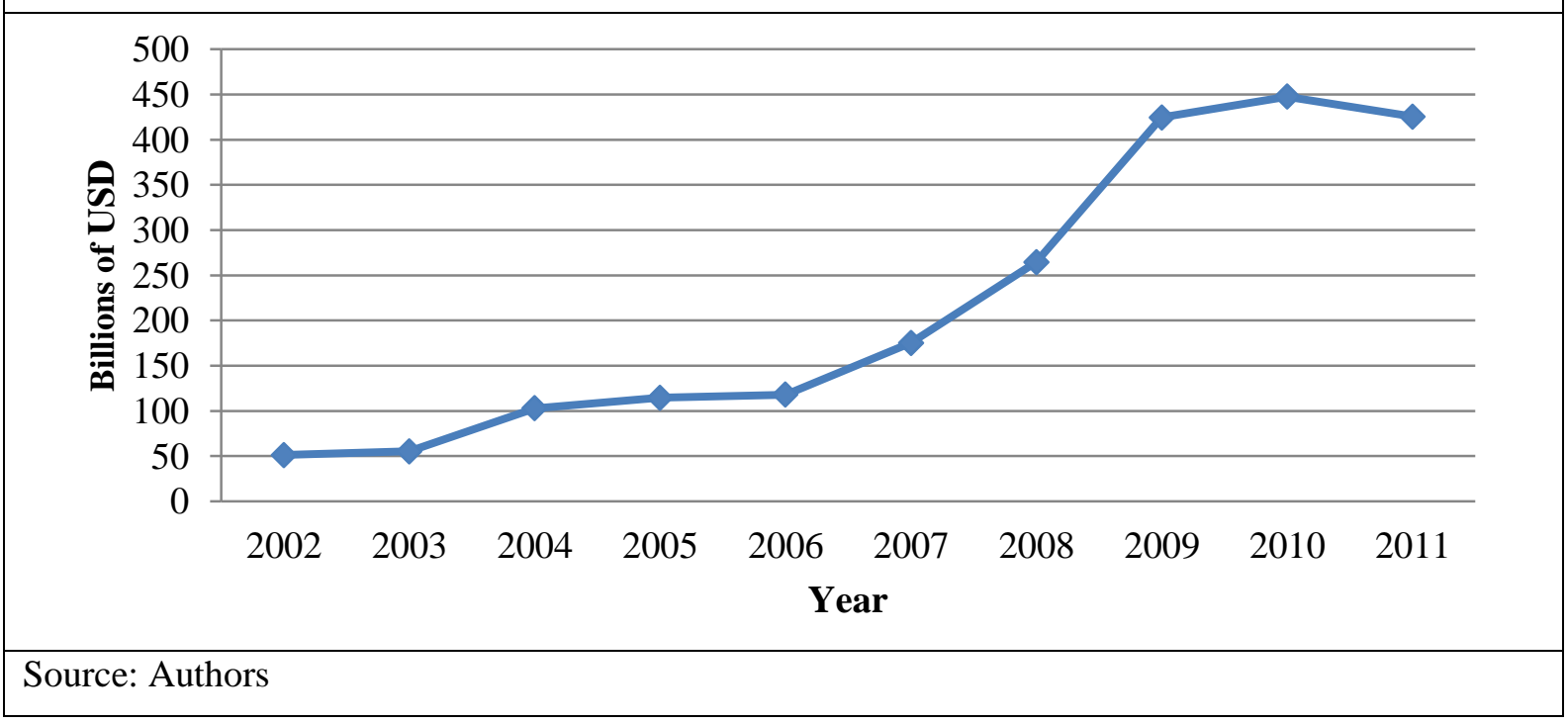


Using the technique described above, we carried out a cluster analysis in Russian corporations' financial borrowing market. Thus, we have highlighted the following clusters: private lenders (commercial banks and private sector corporations), government (federal and municipal government authorities), financial-industrial groups (associations of industrial enterprises and banks), and banks with state participation in the capital structure.

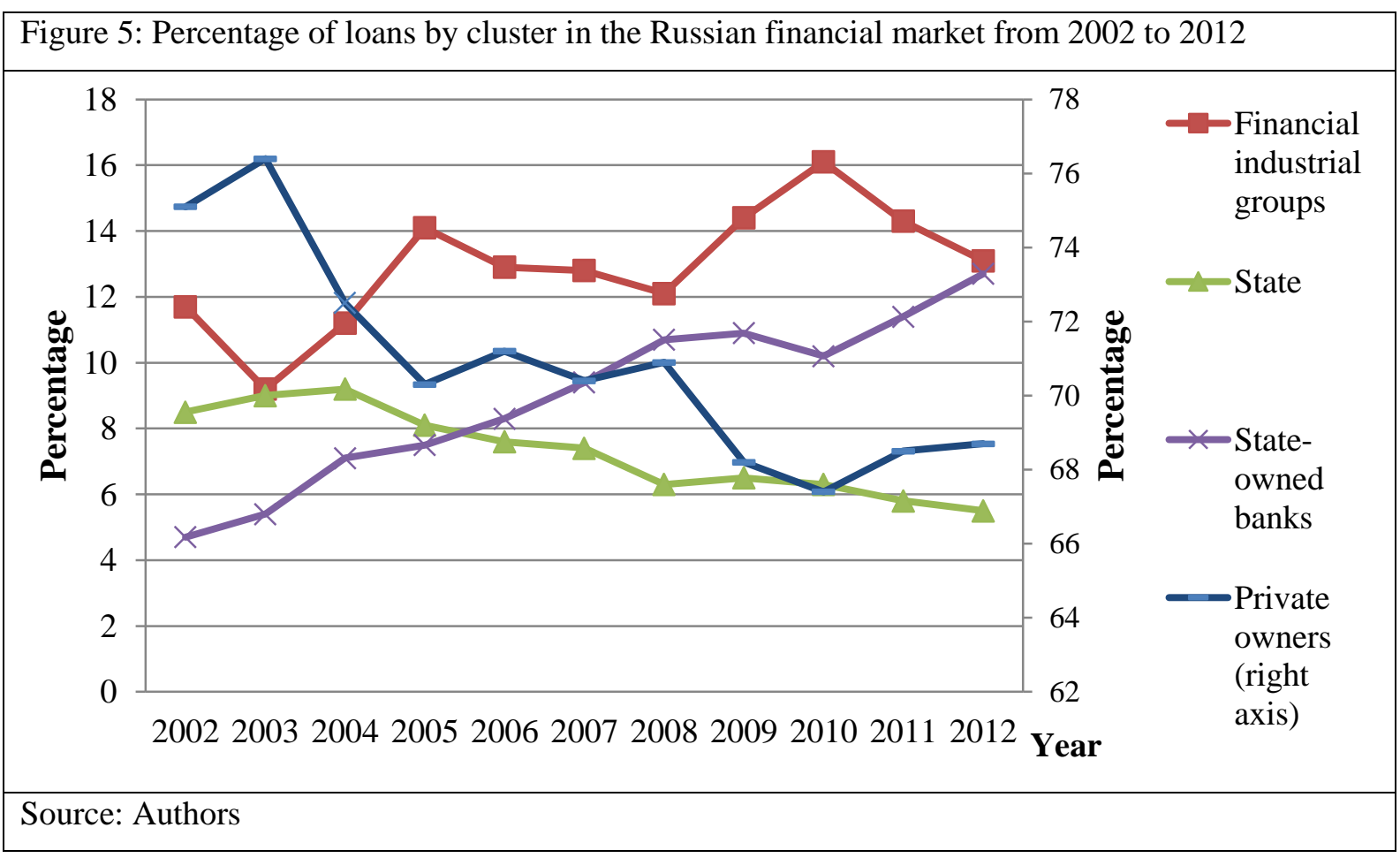

As seen in Figure 5, the largest share in the structure of loans in the financial market is occupied by private lenders, which are the main representatives of commercial banks, including foreign capital. Their share in the loan during the period of 2002 to 2012 has an average of $70.87 \%$. Moreover, this proportion tends to decrease due to an increase in the proportion of other clusters. Thus, the share of banks with state participation increased from $4.7 \%$ to $12.7 \%$ in 2002 and at the end of 2012, respectively. This is explained by the penetration of state structures in the banking sector and the formation of "personal unions," as mentioned earlier. PPG growth share also increased over the period from $11.7 \%$ to $13.1 \%$.

This illustration of the credit market is characterized by increasing levels of monopolization of the market. Since the proportion of the State's participation in the process of raising capital through commercial banks is increasing every year, which indicates increased control over the investment process in the country's economy on the one hand and reduces the effectiveness of the intended use of raised through loans means on the other.

\section{Conclusion}

Processes of globalization and integration of national economies into the global economy are directly dependent on the development prospects of the Russian financial market, as well as the efficiency of its use for economic growth. Distinctly working in all its segments, security market will diversify the savings available for Russian corporations in innovation, and engage investment resource population in economic turnover using new algorithms of modernization.

Fuzzy set theory proposes to transform the source data for the simulation, as well as targets for the optimality of the investment portfolio (profitability, risk, and liquidity) as a vector of interval values. Operating the fuzzy intervals with the necessary input data, ultimately, decision-makers and 
other stakeholders get the final fuzzy interval for each target efficiency indicator of a created investment portfolio.

Terms of forecasting have a direct impact on the limits of possible values of the original data, and, accordingly, the resulting indicators. Thus, in the long term, the interval of required quantity change understandably increases. This provision allows the investment to expand the boundaries of modeling, not taking into account the premise of the classical school of portfolio theory of one-step optimization.

Occurring in the modern Russian economy, transformations of the financial market institutions necessitate revision of tools and mechanisms to mobilize capital, including through the credit market; because its processes occurring on the movement of capital depends largely on the state of the economy and financial stability of its members. Conditions of uncertainty and risk increase the importance of developing new methods and approaches to analyze trends of capital mobilization, in order to predict the state of the financial market, with regard to external and internal factors affecting the national economy and behavioral features of the functions of its subjects.

Ideally, the process of financial integration should stimulate economic growth, promote optimal allocation of financial capital, and enhance development of the economy as a whole. Formation of a diversified investment portfolio allows us to level the total risks in view of the presence of a specific component in the risk map of the investment project. Addressing the role of the State as one of the key actors, involved in the mobilization of financial capital through the credit market, will allow the mechanism to adjust it in the direction of growth of bank lending tools profitability, while increasing growth of the real sector of the Russian economy.

\section{References}

Barhatov, I. V. (2009). Rinok cennih bumag v usloviyah transformacii rossiyskoy economiki. [The stock market in transformation of the Russian economy]. CSU Bulletin, Economy, 1(17), 116-119.

Fisher, I. (1933). The Debt-Deflation Theory of Great Depressions. Econometrics, 1(4).

Hilferding, R. (1910). Das Finanzkapital. Eine Studie über die jüngste Entwicklung des Kapitalismus, Vienna, Wiener Volksbuchhandlung.

Knight, R. (2012). Time Traveler: The Art of Charles R. Knight. Scientific American.

Lenin, V. I. (1969). Polnoe sobranie sochineniy (5th ed.) [Omnibus edition of works]. Moscow: Politizdat, 337.

Lin, T. C. (2012). A Behavioral Framework for Securities Risk. Seattle University Law Review, 34(325).

Markowitz, H. (1952). Portfolio Selection. The Journal of Finance, 7(1), 77-91.

Markowitz, H. (2008). The Concise Encyclopedia of Economics. Library of Economics and Liberty (Second Ed.). Liberty Fund.

Taleb, N. (2008). Infinite Variance and the Problems of Practice. Complexity, 14(2).

Thomas, I. P., (2010). Monthly Review, 61(11).

Tryon, R.(1939). Cluster analysis. London: Ann Arbor Edwards Bros, 139.

Zadeh, L. A. (2005). Toward a Computational Theory of Precisiation of Meaning Based on Fuzzy Logic-the Concept of Cointensive Precisiation. 11th World Congress of International Fuzzy Systems Association IFSA 2005. Beijing: Tsinghua University Press, Springer. 